\title{
JIMMBA
}

Jurnal IImiah Mahasiswa Manajemen, Bisnis dan Akuntansi

Homepage: http://journal.stieputrabangsa.ac.id/index.php/jimmba/index

\section{Analisis Perbandingan Capital Asset Pricing Model Dan Arbitrage Pricing Theory dalam Memprediksi Return Saham pada Perusahaan Telekomunikasi Periode 2016-2018}

Tri Wahyuni' ${ }^{1}$ Eni Kaharti²

1,2Sekolah Tinggi Ilmu Ekonomi Putra Bangsa

Email: afsheentrymyesha@gmail.com¹, enika.azzahra2174@yahoo.com²

\begin{tabular}{l}
\multicolumn{1}{c}{ ARTICLE INFO } \\
\hline Article History: \\
Received: September $16^{\text {th }}$ \\
2020 \\
Accepted: October $16^{\text {th }} 2020$ \\
Published: October $22^{\text {th }} 2020$ \\
Keywords: CAPM, APT, \\
telecoms stock, Expected \\
Return.
\end{tabular}

\section{Pendahuluan}

Perkembangan dunia investasi di pasar modal saat ini menjadi trend dunia, banyak kalangan masyarakat dan investor tertarik untuk menanamkan sebagian dari dananya untuk modal dimasa yang akan datang. Investasi adalah kegiatan usaha yang mengandung risiko karena langsung berhadapan dengan unsur ketidakpastian. Investor akan bisa dengan cepat memperbaiki keputusan investasinya jika mereka mempelajari dan memperhatikan dengan teliti faktor-faktor yang mempengaruhi harga sekuritas, yaitu harapan investor serta penawaran dan permintaan. Saat ini perusahaan telekomunikasi merupakan salah satu industri yang sangat kompetitif dan dinamis. Sub sektor telekomunikasi mengalami perkembangan yang sangat signifikan sejak pemerintah mengijinkan pihak swasta untuk menyelenggarakan jaringan dan jasa komunikasi. 
Berikut berita yang dikutip dari CNN Indonesia tahun 2016 tentang rata-rata kinerja emiten sektor telekomunikasi:

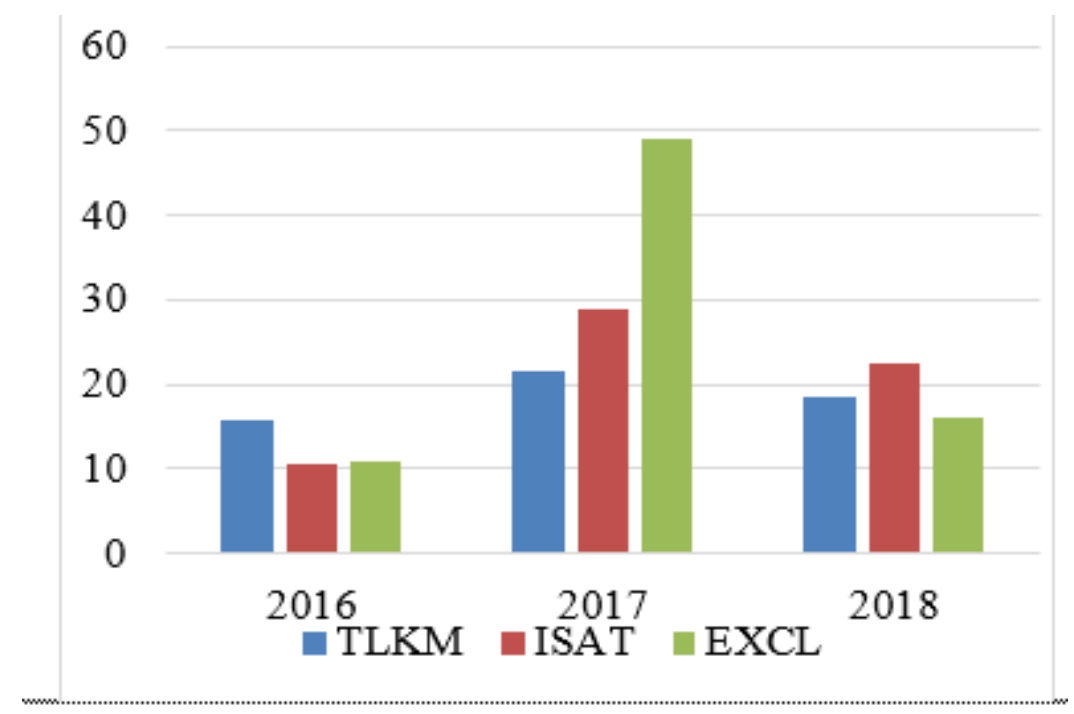

\section{Gambar 1. Laba Bersih Perusahaan Telekomunikasi}

Berdasarkan gambar tersebut dapat diketahui bahwa rata-rata kinerja emiten sektor telekomunikasi menorehkan kinerja yang positif pada pertengahan tahun 2016. Hal ini terlihat dari beberapa emiten yang mencatat kenaikan laba bersih karena ditopang pendapatan data, terkerek tren smartphone. PT Telekomunikasi Indonesia Tbk (TLKM) membukukan pendapatan tertinggi dengan kenaikan 15,58 persen atau Rp56,45 triliun dari sebelumnya Rp48,84 triliun. Bila diilihat, pendapatan tertinggi berasal dari internet dan data selular, yaitu Rp14,61 triliun atau tumbuh 71,68 persen dari Rp8,51 triliun. Pertumbuhan ini tentu berdampak positif terhadap laba bersih perusahaan yang tumbuh sebesar 33,28 persen dari Rp7,44 triliun menjadi Rp9,92 triliun. Analis Millenium Danatama Sekuritas M. Al Amin menyatakan, kinerja emiten Telkom ini jauh di atas ekspektasi di mana laba yang diraih perusahaan hampir 79,8 terhadap konsensus. Ia meyakini, Telkom masih akan memimpin sektor telekomunikasi hingga tahun depan.

Return yang tinggi dalam investasi didukung dengan perkembangan pasar modal yang pesat, yaitu menaiknya Indeks Harga Saham. Suatu hal yang perlu diketahui adalah bahwa investasi pada saham merupakan investasi yang berisiko. Faktor-faktor makro ekonomi tersebut membuat keadaan dilapangan semakin kompleks sehingga investor memerlukan alat untuk memproyeksikan return suatu saham, sesuai dengan risikonya secara sederhana. Salah satunya dengan menggunakan metode keseimbangan. Model keseimbangan yang digunakan dalam memprediksi return dan risiko saham yaitu Capital Assets Pricing Model (CAPM) dan Arbitrage Pricing (APT). 
Berdasarkan fenomena yang menjadi latar belakang, maka penulis tertarik untuk melakukan penelitian dengan judul "Analisis Perbandingan Capital Asset Pricing Model Dan Arbitrage Pricing Theory Dalam Memprediksi Return Saham Perusahaan Telekomunikasi Tahun 2016-2018". 


\section{Kajian Teori dan Telaah Literatur}

Teori portofolio adalah pendekatan investasi yang diprakarsai oleh Harry M. Markowitz, dan pada tahun 1952 teori tersebut dipublikasi secara luas pada Journal of Finance. Halim (2003:50) menyatakan bahwa portofolio merupakan kombinasi atau gabungan atau sekumpulan assets, baik berupa real assets maupun financial assets yang dimiliki oleh investor.

\section{Return Saham}

Menurut Jogiyanto (2010:205), Return Saham adalah nilai yang diperoleh sebagai hasil dari aktivitas investasi. Tandelilin (2010:47) mengemukakan bahwa return merupakan salah satu faktor yangmemotivasi investor berinteraksi dan imbalan atas keberanian investor dalam menanggung risiko atas investasi yang dilakukannya. Return adalah keuntungan yang diperoleh investor dari dana yang ditanamkan pada suatu investasi.

\section{Capital Asset Pricing Model (CAPM)}

Capital Asset Pricing Model Menurut Tandelilin (2010:187) Capital Asset Pricing Model (CAPM) merupakan suatu model yang menghubungkan tingkat return harapan dari suatu aset berisiko dengan risiko oleh teori portofolio pada kondisi pasar yang seimbang. CAPM merupakan model untuk menentukan harga suatu aset padakondisi ekuilibrium. Tujuannya adalah untuk menentukan tingkat pengembalian dari investasi yang berisiko. Menurut Tandelilin (2010:186) model CAPM dapat di ukur menggunakan rumus:

$$
E\left(\boldsymbol{R}_{i}\right)=\boldsymbol{R}_{f}+\boldsymbol{\beta}_{i}\left[E\left(\boldsymbol{R}_{m}\right)-\boldsymbol{R}_{f}\right]
$$

Dimana:

$\mathrm{E}(\mathrm{Ri}) \quad=$ Return harapan aset ke-i

$\mathrm{E}(\mathrm{Rm}) \quad=$ Return harapan portofolio pasar

$\mathrm{Rf}=$ Tingkat bunga bebas risiko (SBSN)

$[\mathrm{E}(\mathrm{Rm}-\mathrm{Rf})] \quad=$ Premi risiko pasar

$\mathrm{Bi} \quad=$ Risiko aset ke-i

\section{Arbitrage Pricing Theory (APT)}

Menurut Syahrial (2014:181), teori APT pada dasarnya menggunakan pemikiran yang menyatakan bahwa dua kesempatan investasi yang mempunyai karakteristik yang identik sama, tidaklah bisa dijual pada harga yang berbeda, apabila dijual pada harga berbeda maka akan terdapat kesempatan untuk melakukan arbitrage. APT adalah 
sebuah model asset pricing yang didasarkan pada sebuah gagasan bahwa pengembalian sebuah aset dapat diprediksi dengan menggunakan hubungan yang terdapat diantara aset yang sama dan faktor-faktor resiko secara umum. Model Keseimbangan APT dapat ditentukan return aktual untuk sekuritas i dengan menggunakan rumus:

$$
R i=E(R i)+b i 1 f 1+b i 2 f 2+\ldots+b i n f n+e i
$$

Keterangan :

$\mathrm{Ri} \quad=$ tingkat return aktual sekuritas $\mathrm{i}$

$\mathrm{E}(\mathrm{Ri})=$ return yang diharapkan untuk sekuritas $\mathrm{i}$

$\mathrm{f}=$ defiasi faktor sistematis $\mathrm{F}$ dari nilai yang diharapkan

bi $\quad=$ sensitivitas sekuritas $\mathrm{i}$ terhadap faktor $\mathrm{i}$

ei $\quad=$ random error

\section{Metode Penelitian}

Penelitian ini dilakukan pada perusahaan Telekomunikasi yang terdaftar di BEI periode 2016-2018. Pengambilan sampel menggunakan metode purposive sampling. Populasi yang digunakan dalam penelitian ini sebanyak 5 perusahaan dengan sampel penelitian sebanyak 4 perusahaan.

Teknik pengumpulan data yang dilakukan dalam penelitian ini yaitu dengan menggunakan teknik dokumentasi. Data yang digunakan dalam penelitian ini merupakan data sekunder yaitu data yang berasal dari website resmi Bank Indonesia, website resmi Yahoo Finance. Alat bantu pengolahan data menggunakan microsoft excel dan SPSS for windows versi 22.0. Teknik analisis data yang digunakan meliputi: (1) Analisis Statisktik Deskriptif, (2) Uji Asumsi Klasik, (3) independent sample t-test. 


\section{Hasil dan Pembahasan}

\section{Analisis Statistik Deskriptif}

Analisis statitik deskriptif digunakan untuk menganalisa data dengan cara mendeskripsikan atau menggambarkan data yang telah terkumpul sebagaimana adanya tanpa bermaksud membuat kesimpulan (Sugiono, 2011).

\section{Uji Independent Sample T-Test}

Karena data berdistribusi normal maka dapat dilakukan uji beda independent sample t-test, hasil perhitungan independen sample t-test dapat dilihat pada tabel dibawah ini.

Tabel 1. Group Statistics

\begin{tabular}{cccccc}
\hline & MAD & $\mathrm{N}$ & Mean & $\begin{array}{c}\text { Std. } \\
\text { Deviation }\end{array}$ & $\begin{array}{c}\text { Std. } \\
\text { Error } \\
\text { Mean }\end{array}$ \\
\hline HASIL & CAPM & 12 & -.454848 & .3420137 & .0987308 \\
& APT & 12 & -.435426 & .3493329 & .1008437 \\
\hline Sumber: Data sekunder diolah (2020) & &
\end{tabular}

Berdasarkan output "group statistik" diatas dapat dilihat bahwa CAPM memiliki nilai rata-rata sebesar -0,454848 denan nilai Std. Deviation sebesar 0,3420137. sedangkan APT memiliki nilai rata-rata sebesar $-0,454848$ dengan nilai Std. Deviation sebesar 0,3493329 .

Tabel 2. Independen Sample t Test

\begin{tabular}{|c|c|c|c|c|c|c|c|}
\hline & \multicolumn{3}{|c|}{$\begin{array}{l}\text { Levene's Test for } \\
\text { Equality of Variances }\end{array}$} & \multicolumn{4}{|c|}{ t-test for Equality of Means } \\
\hline & Sig. & t & df & $\begin{array}{l}\text { Sig. (2- Mean } \\
\text { tailed) Difference }\end{array}$ & $\begin{array}{l}\text { Std. Error } \\
\text { Difference }\end{array}$ & $\begin{array}{c}95 \% \\
\text { Confidence } \\
\text { Interval of } \\
\text { the } \\
\text { Difference } \\
\end{array}$ & $\begin{array}{c}95 \% \\
\text { Confidence } \\
\text { Interval of the } \\
\text { Difference }\end{array}$ \\
\hline & & & & & & Lower & Upper \\
\hline CAPM & .789 & -.138 & 22 & $.892 \quad .2732606$ & .1411284 & -3121044 & .2732606 \\
\hline $\begin{array}{ll}\text { HASIL APT } \\
\end{array}$ & & -.138 & 21.990 & $.892 \quad .2732682$ & .1411284 & -.3121120 & .2732682 \\
\hline
\end{tabular}

Berdasarkan output "Independent Samples Test" pengolahan data menggunakan SPSS 22 yang di tunjukan oleh tabel IV-14 diketahui nilai sig. (2-tailed) sebesar 0,892>0,05 
maka dapat disimpulkan bahwa $\mathrm{H}_{0}$ diterima dan $\mathrm{H}_{a}$ ditolak. Tabel output "Mean Difference" adalah sebesar 0,2732606. Nilai ini menunjukkan selisih antara rata-rata nilai CAPM dan APT sebesar -0,3121044 sampai 0,2732606 (95\% Confidence Interval of the Difference). Nilai $t_{\text {hitung }}$ sebesar $-0.138<t_{\text {tabel }}$ sebesar 2.2009 maka dapat disimpulkan bahwa $\mathrm{H}_{0}$ diterima dan $\mathrm{H}_{\mathrm{a}}$ ditolak artinya tidak terdapat perbedaan antara CAPM dan APT dalam memprediksi return saham Telekomunikasi. Hasil ini sesuai dengan penelitian terdahulu yang dilakukan oleh Gancar Candra Premanto (2004), Sulistiarini Widianita (2009), Musdalifah Azis 2010, dan Hielmiyani Maftuhah (2014) dimana hasil menunjukkan bahwa metode CAPM lebih akurat dibandingkan metode APT dalam memprediksi return saham yang diukur dengan menghitung nilai MAD, tetapi tidak terdapat perbedaan yang signifikan antara MAD_CAPM dan MAD_APT. 


\section{Penutup dan Saran}

\section{Simpulan}

Berdasarkan hasil analisis data dan pembahasan yang telah diuraikan, maka kesimpulan yang dapat diambil yaitu sebagai berikut:

1. Nilai return saham Telekomunikasi yang dihitung dengan metode CAPM dari yang terkecil hingga yang terbesar adalah ISAT (-1.0659), EXCL (-0.8584), EXCL (-0.7562), ISAT (-0.6279), TLKM (-0.5498), FREN (-0.4608), FREN (-0.4368), ISAT (-0.3273), TLKM (-0.2341), TLKM (-0.1826), EXCL (-0.0989), FREN (0.1405).

2. Nilai return saham Telekomunikasi yang dihitung dengan metode APT dari yang terkecil hingga yang terbesar adalah ISAT (-1.1169), EXCL (-0.8187), EXCL (-0.7447), TLKM (-0.61984), ISAT (-0.5936), FREN (-0.4089), FREN (-0.3577), ISAT (-0.2277), TLKM (-0.2130), TLKM (-0.0868), EXCL (0.0822), FREN (0.0449).

3. Berdasarkan hasil perhitungan nilai Mean Absolute Deviation (MAD) dari kedua model, rata-rata MAD CAPM sebesar $(-0,45484)$ dan nilai MAD APT sebesar (0,43543). Kedua nilai tersebut hanya selisih -0.01941 .

4. Pricing Model (CAPM) dengan Arbitrage Pricing Theory (APT) dalam memprediksi return saham Telekomunikasi. $\mathrm{H}_{0}$ diterima karena nilai Sig $=0.789>$ 0.05. Nilai thitung sebesar $-0.138<t_{\text {tabel }}$ sebesar 2.2009 .

\section{Saran}

a. Bagi Investor

Bagi Investor hasil penelitiaan ini diharapkan mampu dijadikan sebagai informasi mengenai perkembangan investasi saham pada perusahaan Telekomunikasi. Investor harus mempertimbangkan secara matang mengenai beberapa hal yang sangat penting dalam pengambilan keputusan investasi yang dilakukannya.

b. Bagi Perusahaan

Bagi Perusahaan Hasil Penelitian ini dapat dijadikan informasi tambahan dan pertimbangan bagi perusahaan dalam melakukan kebijakan yang berhubungan dengan investasi

c. Bagi Peneliti Selanjutnya

Dapat memperluas penelitian dengan menambah sampel perusahaan dan memperpanjang jumlah periode penelitian.dan memperluas atau menambahkan variabel makro pada perhitungan expected return metode APT. Sehingga dapat diketahui variabel makro lain yang dapat mempengaruhi hubungan return suatu perusahaan sehingga metode APT dapat lebih akurat dalam memprediksi return saham dibandingkan metode CAPM. 


\section{Referensi}

DePorter, B., \& Hernacki, M. (2002). Quantum Learning: Membiasakan Belajar Nyaman dan Menyenangkan. (terjemahan Alwiyah Abdurrahman). Bandung: Kaifa (Buku asli diterbitkan tahun 1992. New York: Dell Publishing).

Fahmi, I. (2014). Pengantar Manajemen Keuangan Teori dan soal jawab. Bandung: ALFABETA

Ghozali, I. (2011). Aplikasi Analisis Multivariete dengan Program IBM SPSS 23. Cetakan Kedelapan. Semarang: Badan Penerbit Universitas Diponegoro.

Hartono, J. (2010). Teori Portofolio dan Analisis Investasi, Edisi Ketujuh, Yogyakarta: Fakultas Ekonomika dan Bisnis UGM.

Hartono, J. (2014). Teori Portofolio dan Analisis Investasi. Yogyakarta: Universitas Gajah Mada.

Husnan, S. (2005). Dasar-dasar Teori Portofolio dan Analisis Sekuritas Edisi Ketiga Cetakan Kedua. Yogyakarta: AAMP YKPN.

Indra, Y. A. (2018). Perbandingan Keakuratan Metode Capital Asset Pricing Model dan Arbitrage Pricing Theory dalam Memprediksi Return Saham (Studi pada Perusahaan Sektor Barang Konsumsi dan Sektor Pertambangan yang Terdaftar di Indeks Saham Syariah Indonesia (ISSI) Peri. COSTING: Journal of Economic, Business and Accounting, 1(2), 233-240.

Komara, E. F., \& Yulianti, E. ANALISIS PERBANDINGAN CAPM DENGAN TFMFF DALAM MENGESTIMASI RETURN SAHAM PADA JII PERIODE 20142016. Manajerial: Jurnal Manajemen dan Sistem Informasi, 18(1), 41-53.

Laia, K., \& Saerang, I. (2015). Perbandingan Keakuratan Capital Assets Pricing Model (CAPM) dan Arbitrage Pricing Theory (APT) Dalam Investasi Saham Pada Bank Umum Swasta Nasional Devisa Yang Terdaftar di BEI. Jurnal $E M B A, 3(2), 247-257$.

Lemiyana, L. (2015). Analisis Model CAPM dan APT Dalam Memprediksi Tingkat Return Saham Syariah (Studi kasus Saham di Jakarta Islamic Index). I-Finance: a Research Journal on Islamic Finance, 1(1), 1-20.

Masithoh, L. (2017). Pengujian Validitas Capital Asset Pricing Model (CAPM), Islamic Capital Asset Pricing Model (ICAPM) dan Arbitrage Pricing Theory (APT) dalam Memprediksi Return Saham Syariah di Jakarta Islamic Index (Periode Tahun 2012-2016). Thesis. Fakultas Ekonomi dan Bisnis UIN Syarif Hidayatullah Jakarta.

Sujimat, D. A. (2000). Penulisan karya ilmiah. Makalah disampaikan pada pelatihan penelitian bagi guru SLTP Negeri di Kabupaten Sidoarjo tanggal 19 Oktober 2000 (Tidak diterbitkan). MKKS SLTP Negeri Kabupaten Sidoarjo

Suparno. (2000). Langkah-langkah Penulisan Artikel Ilmiah dalam Saukah, Ali dan Waseso, M.G. 2000. Menulis Artikel untuk Jurnal Ilmiah. Malang: UM Press.

Wahab, A., \& Lestari, L. A. (1999). Menulis Karya Ilmiah. Surabaya: Airlangga University Press. 
Jurnal Ilmiah Mahasiswa Manajemen, Bisnis dan Akuntansi 2(5) Oktober 2020

Winardi, G. (2002). Panduan Mempersiapkan Tulisan Ilmiah. Bandung: Akatiga. 